\title{
Sobre a forma ocupacional após acidente por queimaduras $^{1}$
}

\author{
Elson Ferreira Costa, Luísa Sousa Monteiro Oliveira, Victor Augusto Cavaleiro Corrêa
}

Universidade Federal do Pará - UFPA, Belém, PA, Brasil.

\begin{abstract}
Resumo: Introdução: As ocupações são atividades nas quais as pessoas se envolvem diariamente, possuem finalidades, significados e se estendem ao longo do tempo. Diversas situações podem influenciar o engajamento nas ocupações, principalmente, as alterações nas condições de saúde, como a queimadura. Objetivo: Compreender como se apresentavam as ocupações de pessoas após o acidente por queimaduras e quais as repercussões, especialmente sobre a forma ocupacional após a queimadura. Método: Trata-se de uma pesquisa de natureza qualitativa, ancorada na perspectiva fenomenológica. Foi realizada no Centro de Tratamento de Queimados, do Hospital Metropolitano de Urgência e Emergência do Pará, no período de dezembro de 2010 a janeiro de 2011. Participaram da pesquisa 19 pessoas. Sob o enfoque teórico da Ciência da Ocupação, o estudo centrou-se na investigação das repercussões da queimadura na forma ocupacional. Resultados: Os resultados do estudo revelaram que ocorreram significativas mudanças nas ocupações após os acidentes. Essas mudanças repercutiram na saúde, bem-estar e qualidade do viver das pessoas. As principais alterações estavam relacionadas com limitações físico-funcionais e consequências psicoemocionais. Conclusão: Considera-se que este estudo contribuiu para o aprimoramento do conhecimento quanto à problemática das repercussões da queimadura para a ocupação humana, a partir de uma perspectiva ampliada e integral da saúde e da compreensão biopsicossocial e ocupacional do ser humano.
\end{abstract}

Palavras-chave: Queimaduras, Ocupação, Terapia Ocupacional.

\section{The occupational form after a burn accident}

\begin{abstract}
Introduction: The occupations are activities in which people engage daily, with purposes, meanings and extention over time. Several situations can influence the engagement in occupations, especially changes in health conditions such as burns. Objective: To understand the occupations of people after a burn accident and their repercussions, especially on the occupational form following the accident. Method: Qualitative research, anchored in the phenomenological perspective, held at the Burn Treatment Center of the Metropolitan Ungency and Emergency Hospital of Para, from December 2010 to January 2011. Nineteen people participated under the theoretical approach of the Science of Occupation, in which the study focused on the investigation of burn impact on occupational form. Results: The study results revealed significant changes in the occupational form, affecting the health, well-being and quality of life of those people. The main changes were related to physical and functional limitations and psycho-emotional consequences. Conclusion: This study contributed to improve the knowledge about the burn repercussions issue for human occupation from an expanded and comprehensive perspective of health, biopsychosocial and human occupational understanding.
\end{abstract}

Keywords: Burns, Occupation, Occupational Therapy.

\footnotetext{
Autor para correspondência: Victor Augusto Cavaleiro Corrêa, Faculdade de Fisioterapia e Terapia Ocupacional, Instituto de Ciências da Saúde, Universidade Federal do Pará, Av. Generalíssimo Deodoro nº 1, Umarizal, CEP 66050-060, Belém, PA, Brasil, e-mail: victorcavaleiro@gmail.com Recebido em Out. 21, 2016; $1^{\text {a }}$ Revisão em Fev. 1, 2017; Aceito em Abr. 6, 2017.
} 


\section{Introdução}

As ocupações são atividades nas quais as pessoas necessitam se envolver diariamente, possuem finalidades, atenção, significado, formadas por múltiplas tarefas e se estendem ao longo do tempo (CHRISTIANSEN; BAUM; BASS-HAUGEN, 2005. Para Wilcock (1993), a ocupação tem três finalidades básicas: satisfação das necessidades pessoais, desenvolvimento de competências e aquisição de habilidades pessoais para a manutençáo da saúde e desenvolvimento do organismo. Além disso, são nomeadas e organizadas individualmente, mas a partir da cultura na qual a pessoa está inserida. Diversas situaçóes podem influenciar o engajamento nas ocupaçōes, principalmente, as alteraçôes nas condiçôes de saúde, como a queimadura.

A queimadura é uma lesão na pele e anexos, na qual ocorre a destruição parcial ou total dos mesmos, em decorrência de um trauma, que pode ser de origem térmica, elétrica, química ou radioativa (RODRIGUES JÚNIOR; BASTOS; COELHO, 2014). A gravidade e o prognóstico dessa injúria são identificados a partir do agente causal, da profundidade, da extensão, da superfície, localização corporal, entre outros (LEÂO et al., 2011). As queimaduras são atualmente um grave problema de saúde pública, não só quanto à seriedade e complicações, mas também em relação às sequelas ocasionadas (RODRIGUES JÚNIOR; BASTOS; COELHO, 2014).

A experiência da queimadura é uma das mais traumáticas e dolorosas que uma pessoa pode vivenciar. É um acontecimento geralmente inesperado que modifica drasticamente o cotidiano, no qual o sujeito ativo torna-se impossibilitado de dar continuidade a suas atividades nas esferas biopsicossocial e ocupacional (LIRA; SILVA; SOANÉGENES, 2013). O corpo pode ficar desfigurado, sem a pele que o recobre. Em muitos casos são necessários procedimentos cirúrgicos, como a enxertia, que é um processo doloroso e que pode desfigurar ainda mais o corpo (ECHEVARRÍA-GUANILO et al., 2016). Além disso, há a possibilidade de sequelas e a incerteza de não saber se voltará ao seu pleno desempenho ocupacional ${ }^{2}$.

Siqueira e Juliboni (2000), Arruda, Braide e Nations (2014) e Souza (2011) afirmam que, com o decorrer do tempo, a pessoa queimada vai elaborando o que lhe aconteceu e também manifesta dúvidas de como seu corpo ficará. Podem surgir preocupaçóes com a possibilidade de o trauma provocar cicatrizes, sequelas estéticas e/ou deformidades. Sendo assim, as consequências deixadas pela queimadura podem afetar habilidades e capacidades funcionais e psicoemocionais para a realização de tarefas diárias. Esses comprometimentos podem afetar a autonomia, a independência, o bem-estar, a qualidade de vida e o envolvimento em ocupaçôes (RODRIGUES JÚNIOR; BASTOS; COELHO, 2014).

Acredita-se que os aspectos relacionados ao engajamento ocupacional após a queimadura ainda são pouco enfatizados na literatura científica da terapia ocupacional. Diante disso, surgiu o interesse em investigar este trauma e suas implicaçóes para as ocupaçóes, além de compreender como se apresentavam as ocupaçóes dessas pessoas após o acidente. Para a Ciência Ocupacional, a ocupação é definida como unidades de ação, que são contínuas, intencionais e conscientemente executadas. Neste campo de atuação, a ocupaçáo é considerada o foco central do exercício da prática da terapia ocupacional, assim como a unidade de análise desta ciência (ARAÚJO et al., 2011; LARSON; WOOD; CLARCK, 2005; PINOCHET; ARISMENDI; CASTILLO, 2013).

A Ciência Ocupacional se centra na forma, função e no significado da ocupação humana. A forma se refere aos aspectos que são diretamente observáveis. A função se refere ao modo como a ocupação influencia o desenvolvimento, a adaptação, a saúde e a qualidade de vida. Por fim, o significado se refere à experiência subjetiva da participação em fazeres, sendo atribuídos valores pessoais às vivências. As ocupaçóes estão simbolicamente constituídas em uma cultura e são interpretadas a partir do contexto da história de vida das pessoas (ARAÚJO et al., 2011; LARSON; WOOD; CLARCK, 2005; PINOCHET; ARISMENDI; CASTILLO, 2013). Nessa esfera multifatorial, se considera o homem como ser ocupacional.

Em decorrência da queimadura e de seus desdobramentos, supóe-se que a pessoa queimada passe a vivenciar situaçôes novas, podendo ocorrer alteraçôes em vários âmbitos ocupacionais. Essas condiçóes provocaram questionamentos sobre quais, como ou de que maneira a queimadura pode repercutir nas ocupaçóes dessas pessoas? Qual a forma ocupacional após a queimadura? Desse modo, este estudo teve o objetivo de compreender como se apresentavam as ocupaçóes de pessoas após o acidente por queimaduras e quais as repercussóes, especialmente sobre a forma ocupacional após a queimadura. 


\section{Método}

Esta pesquisa foi ancorada na abordagem qualitativa, tendo como base a concepção fenomenológica, que busca desvelar os sentidos contidos nos discursos das pessoas envolvidas na pesquisa (TURATO, 2005). A pesquisa, que tem uma metodologia qualitativa na área da saúde, não deve estudar o fenômeno em si, mas compreender o significado individual ou coletivo para a vida das pessoas. Por isso, é imprescindível conhecer o que os fenômenos da doença e da vida em geral representam para elas. Este significado tem função estruturante, ou seja, saber como as pessoas organizam seu modo de vida, incluindo seus cuidados com a saúde (TURATO, 2005). Nesta perspectiva, Minayo (2012) afirma que o processo de análise na investigação qualitativa possibilita objetivar um tipo de conhecimento que tem como matéria prima crenças, valores, representaçóes, subjetividades e açôes humanas a partir da perspectiva dos atores em intersubjetividade. Foi adotado também o método de análise fenomenológico, o qual trata da descrição das experiências vividas pelos sujeitos pesquisados sobre um determinado fenômeno e propicia ao pesquisador ir além do conteúdo meramente intelectual e alcançar conteúdos internos. Este método é apropriado para pesquisar o mundo do sujeito, seus sentidos e significados da vivência de um determinado acontecimento, construindo, assim, a compreensão de algo (ANDRADE; HOLANDA, 2010).

\subsection{Local da pesquisa}

A coleta de dados foi realizada no Centro de Tratamento de Queimados (CTQ) do Hospital Metropolitano de Urgência e Emergência (HMUE), no município de Ananindeua, no estado do Pará.

\subsection{Participantes da pesquisa}

Participaram da pesquisa 19 pacientes vítimas de queimadura, em acompanhamento ambulatorial no CTQ-HMUE, na faixa etária de 19 a 60 anos e de ambos os sexos.

Utilizou-se como critérios de inclusão: pessoas vítimas de queimadura, com idade a partir de 18 anos, de ambos os sexos e que estivessem em acompanhamento ambulatorial. Estes deveriam aceitar fazer parte do estudo, após a leitura e assinatura do Termo de Consentimento Livre e Esclarecido (TCLE).

Quanto aos critérios de exclusão: pacientes que não estivessem em acompanhamento ambulatorial no Centro de Tratamento de Queimados do HMUE, com faixa etária inferior a 18 anos de idade, ou aqueles que não consentiram a participação na pesquisa.

De maneira geral, no universo das pessoas entrevistadas, houve a predominância do sexo masculino sobre o feminino, no qual havia 12 homens e 7 mulheres. Quanto às características dos participantes, a maioria era de casados, com ensino médio completo e de orientação religiosa católica. O tipo de queimadura predominante foi à térmica, totalizando 11 pessoas. Além delas, havia 8 vítimas de queimaduras elétricas. Para preservar a identidade dos participantes, utilizaram-se nomes fictícios com a temática da mitologia grega.

\subsection{Procedimentos de coleta e análise dos dados}

Os dados do estudo foram obtidos a partir da aplicação de uma entrevista semi-dirigida com os participantes, além de registro em diário de campo. As perguntas norteadoras da entrevista foram: "Como e quando aconteceu a queimadura?"; "Quais eram as suas principais ocupaçóes antes do acidente?"; "O que mudou em sua vida após o acidente?"; "Qual o significado das suas ocupaçóes no momento atual?"; "Como você se sentiu ao responder as perguntas?". Posteriormente, os dados foram tratados através da técnica de análise do conteúdo, definida como um conjunto de técnicas de análise de comunicação que objetiva obter, por procedimentos sistemáticos e objetivos de descrição do conteúdo das mensagens, indicadores, que permitam a inferência de conhecimentos relativos às condiçôes de produção/recepção destas mensagens (MINAYO, 2004; TURATO, 2005).

As entrevistas foram gravadas em áudio com o consentimento dos entrevistados. Estes autorizaram, também, o uso do material para a pesquisa e a sua publicação. As entrevistas foram examinadas a partir das indicaçóes do método fenomenológico, transcritas e depois lidas exaustivamente. Em seguida, foram assinaladas as unidades de significado nos textos. Assim, foram construídos os núcleos de significação, relacionando os discursos dos sujeitos da pesquisa à fundamentação teórica.

\section{Resultados e Discussão}

A queimadura pode acarretar sequelas físico-funcionais e ocupacionais, que podem gerar mudanças na forma de realizar afazeres do dia a dia. Neste estudo, optou-se por discutir a temática das ocupaçóes de pessoas vítimas de queimadura, com 
destaque à forma ocupacional. De acordo com Nelson (1988), a forma ocupacional se refere aos aspectos da ocupação que são diretamente observáveis. É um conjunto de circunstancias objetivas, independentes e externas a uma pessoa. A interseção entre o contexto ambiental, assim como a demanda de tarefas, é classificado como aspecto da forma ocupacional.

Durante as entrevistas, vários participantes pontuaram a dificuldade em se engajar em ocupaçôes que eram desempenhadas antes da queimadura, principalmente no que diz respeito à forma ocupacional. Foram mencionadas, principalmente, as atividades produtivas, autocuidado, lazer, descanso e sono. Entre as causas que dificultavam a realização das ocupaçóes dos participantes deste estudo, destacam-se as sequelas físico funcionais da queimadura, que resultaram em déficits durante a realização das atividades de vida diária (AVD).

As atividades de vida diária são aquelas orientadas para o cuidado do indivíduo para com seu próprio corpo. Estas são fundamentais para o viver, permitem a sobrevivência básica e o bem-estar, incluindo a higiene pessoal, o autocuidado, o banho, a alimentação, o comer, o vestuário, o controle dos esfíncteres, a mobilidade funcional, o cuidado com equipamentos pessoais, a atividade sexual, o uso do vaso sanitário, entre outros (CAVALCANTI et al., 2015; AMERICAN..., 2014).

Através dos relatos dos participantes da pesquisa, observou-se que, durante a fase aguda da queimadura, a realização das atividades da vida diária ficava comprometida. Algumas pessoas, em especial as que foram amputadas, mesmo após a fase aguda, ainda encontravam dificuldade para realizar essa ocupação, necessitando da ajuda de alguém. $\mathrm{O}$ fato de não conseguir engajar-se satisfatoriamente em atividades táo rotineiras e essenciais interferia no retorno ao dia a dia e causava sentimentos de dependência e invalidez, conforme os relatos a seguir.

Eu tenho dificuldade de me limpar, de fazer minhas necessidades fisiológicas [...] É a minha esposa que faz pra mim..., que me limpa, ela que me dá banho, ela que me veste a roupa. As roupas que eu consigo tirar eu tiro, agora pra vestir eu não consigo vestir roupa [...] Pra comer, a Dra fez a parte da colher, você viu eu escrevo, eu não posso épegar nas coisas [...] Eu como sozinho, mesmo se ela não tiver em casa, mas tiver tudo prontinho, eu ponho no prato, pego a colher, coloco na órtese, você sabe o que eu to falando, né? Ai eu dou um jeito e como... (Zeus).

Eu acordava pra ir pro trabalho e tomava café, hoje eu não posso mais tomar café direito, não posso abrir muito a boca [...] Não posso almoçar direito, não posso comer direito, não posso digerir nada diretamente assim, tem que ser mais líquido [...] No banho, mudou um pouco, porque eu não posso molhar muito o rosto, só do pescoço pra baixo, mas no meu rosto assim, pode jogar água, mas não muito, só o necessário [...] Eu fazia tudo isso agora eu não posso fazer totalmente por motivo da queimadura... (Hélio).

Mudou o banho, a higiene. Mudou muita coisa [...] Eu gosto de piscina e eu náo posso tomar mais um banho gostoso como eu tomava antes, teve uma mudança até porque eu tô em tratamento [...] Eu sou destra, então eu tenho que comer do lado esquerdo e não é fácil se adaptar, eu não consigo escrever... (Atena).

Dessa maneira, percebe-se que a pessoa que sofreu queimadura passa a perceber mudanças e a receber auxílios no desempenho ocupacional, provocando um processo de redefinição das atividades ocupacionais. Por meio dos relatos, notam-se dificuldades quanto à execução dos cuidados pessoais, principalmente pelas limitaçôes físicas com características incapacitantes. $\mathrm{O}$ fato de não poder tocar nas partes de seu corpo, não conseguir realizar ou engajar-se em atividades de vida diária táo essenciais como cuidar de sua higiene pessoal gera mudanças significativas. Assim, as consequências do trauma pela queimadura implicam em mudanças na forma ocupacional, ou seja, no modo de desempenhar determinadas ocupaçóes. Percebeu-se ainda que estas pessoas faziam comparaçốes com a condição anterior à queimadura, revelando preocupação quanto ao retorno à condiçấo antecedente a queimadura e tinham dúvidas se após o tratamento iriam conseguir realizar as suas ocupaçóes habituais. A incerteza do retorno às suas ocupaçóes causava desconforto, em especial para os que ficaram com sequelas mais graves, pois estas os impediam de desempenhar seus afazeres da forma ocupacional em que eram realizados.

Nos relatos abaixo, observou-se uma alteraçáo na maneira de se ocupar de forma repentina. A pessoa acometida precisou encontrar mecanismos para adaptar-se e conseguir envolver-se em suas ocupaçôes.

A minha maior dificuldade é porque eu não tô acostumado a usar a mão esquerda, né? Só a direita, então é complicadíssimo. Tudo é difícil, não tem como usar só a esquerda pra quem é destro, né? [...] Por exemplo: comer, eu não consigo comer direito, porque eu não tô acostumado com a mão esquerda, e outras atividades também não tem como fazer, entendeu? (Apolo).

Mudou muita coisa cara [...] O que eu fazia antes, hoje em dia eu não faço, e quando eu tento fazer 
não consigo fazer da maneira que eu conseguia fazer, ai eu sinto muito [...] Fico chateado comigo mesmo [...] Às vezes queria fazer uma coisa em casa, o quintal de casa só vivia limpo, ai minha sogra falou: "antes quando o Thor tava bom, o quintal só vivia limpo, agora só vive sujo", ai quando foi em agosto eu meti a cara, porque eu náo conseguia segurar direito o cabo da enxada, mas mesmo assim com todo sacrifício eu consegui deixar o quintal do jeito que ela gosta (Thor).

Apesar de todas as limitaçóes, essas pessoas sentem um desejo de conseguir desenvolver novamente esses afazeres. Nota-se a angústia, a vontade de superar as dificuldades e as limitaçôes impostas pela queimadura e de provar para as demais pessoas que ainda é capaz de ser alguém produtivo, que se ocupa. No relato de Thor, percebeu-se que, a fim de se adaptar em diferentes ambientes, ele buscou ser flexível para satisfazer as demandas do meio no qual está inserido. Em decorrência disto, modificou a forma de suas ocupaçóes no intuito de mostrar para si mesmo e para os seus familiares que ainda era capaz de realizar os seus afazeres.

A queimadura também interferiu na forma ocupacional durante a execução de Atividades Instrumentais de Vida Diária (AIVD). Entende-se que essas são as atividades que apoiam a vida diária dentro de casa e na comunidade que, frequentemente, requerem maior complexidade de interaçóes do que o autocuidado usado na atividade da vida diária. Em geral, são complexas, opcionais por natureza e incluem: cuidado com o outro, cuidados com animais de estimação e doméstico, criar e cuidar de filho, uso de equipamentos para a comunicação; mobilidade na comunidade, gerenciamento financeiro, cuidado e manutenção da saúde, gerenciamento do lar, preparação da refeição e limpeza, procedimentos de segurança e emergência, fazer compras, entre outros (CAVALCANTI et al., 2015; AMERICAN..., 2014).

Eu tô podendo fazer as coisas, não muito, as coisas que eu posso, eu faço [...] Eu ainda náo posso varrer casa, porque eu tô com esse negócio aqui no braço, atadura [...] Eu faço as coisas assim muito bem, mas quando eu tiro, eu sinto que o meu cotovelo dói ainda, porque eu náo tô fazendo força. Lavar roupa eu ainda náo tô podendo lavar... (Iris).

Agora eu nem tô cuidando de casa... (Artemis).

Algumas pessoas apresentaram limitaçôes físicas por redução na amplitude de movimentos ${ }^{3}$, dores nos membros, na incisão cicatricial, alteraçóes de sensibilidade (como parestesias ${ }^{4}$ ), prurido $^{5}$, edemas e elevação da temperatura. Seus relatos apontaram que estas limitaçóes provocaram modificaçóes na forma ocupacional. Estas disfunçóes os levaram a comparar seu corpo antes e depois do acidente.

Hoje, o movimento dos meus braços, eu não tenho o movimento completo, a minha perna direita não ta dobrando mais [...] Por isso náo to podendo fazer atividade doméstica, tenho que ficar de repouso (Afrodite).

Eu tô com a mão enfaixada ai não dá pra fazer certas coisas, quero tomar um banho direito, mas não pode molhar, não da pra dormir, porque dói um pouco, não posso sair na rua, porque não pode pegar sol, muitas coisas, não posso jogar bola, não posso nem ir pro colégio mais. Tenho dificuldade pra jogar bola, sair, tomar banho, principalmente tomar banho (Cronos).

A presença dessas limitaçóes físicas modificou a forma de realizar as atividades. Essas limitaçóes provocaram a necessidade de solicitar ajuda de outras pessoas para a realização de suas ocupações, gerando sentimento de incapacidade. Estas restriçóes podem fomentar senso de incapacidade, especialmente ao tornarem-nas dependentes de outras pessoas para a realização de suas atividades, incluindo-se o próprio autocuidado. Neste sentido, Siqueira e Juliboni (2000) afirmam que após a fase aguda da queimadura, o paciente pode apresentar sentimentos de insegurança em relação ao retorno aos seus movimentos e a capacidade de conseguir desempenhar suas ocupaçóes como antes. De certa forma, a pessoa adquire uma nova dimensão de seu corpo com a nova pele e terá que redescobri-lo quanto às suas potencialidades $\mathrm{e}$ limitações. Além disso, o incômodo de não poder fazer as coisas ou de não reconhecer o próprio corpo podem continuar presentes (SIQUEIRA; JULIBONI, 2000).

O que me incomoda é meu corpo que náo ficou normal, ficou com essas manchas [...] No começo eu cheguei até a falar besteira, murmurar falar coisas que Deus não gosta [...] Cheguei até a falar que se fosse do jeito pra eu ficar depois que eu tirava as ataduras preferia morrer (Eros).

Pra mim é difícil até sair [...] quando eu saí do hospital não queria nem sair de casa, sentia vergonha [...] A cicatriz [...] as pessoas ficam perguntando se é de nascença, o que é aquilo? Outros ficam pensando que é outra doença, ai a gente fica assim nunca tá satisfeito em um canto [...] As pessoas não me incomodam, mas eu me acho assim [...] Não é assim o que eu era. Ai, hoje eu me sinto até às vezes com vergonha, às vezes até fico me olhando no espelho e me lembrando do jeito quando eu era [...] Bom, ai agora tô nessa situação... (Dionísio). 
Manejar toda essa situação, sem dúvida, não é simples e pode trazer sofrimento náo só para a pessoa acometida, assim como para toda a família, pois terá que reajustar a forma como executa os afazeres. Dessa forma, os familiares terão que auxiliar essas pessoas a desempenharem seus afazeres ocupacionais. Nelson (1988) argumentou que o processo de mundança na forma ocupacional ocorre com influência do processo de adaptação ocupacional. Isso se dá por fatores diversos, como alteraçâo no desempenho ocupacional, habilidades de desempenho e motivaçáo durante a execução de tarefas. Nessa perspectiva, Echeverria, Ortega e Riquelme (2009) mencionam que as modificações no desempenho podem ocorrer porque as ações antes de serem executadas são idealizadas e espera-se um grau de aceitação de outros. Quando as ocupaçóes que o indivíduo realiza não são aceitas pelo seu entorno social, é comum surgirem sentimentos de frustração e insegurança. Ao contrário, quando a pessoa consegue realizar a ocupação mesmo com os déficits ocasionados pela queimadura, podem surgir mecanismos de superação, bem-estar e motivação para planejar e desempenhar ocupaçóes mais elaboradas.

Foram relatadas também mudanças significativas em relaçáo ao engajamento nas atividades produtivas, como o trabalho. Este fato influenciou em vários aspectos ocupacionais, pois algumas pessoas não puderam mais retornar às suas atividades laborativas, outras precisaram trocar de função, pois as limitaçôes as impediram de voltar aos afazeres. Dessa maneira, como a maioria era mantenedora de seus lares e, consequentemente, não poder exercer as atividades laborativas e suprir economicamente a família como antes, isso repercutia negativamente, como se pode verificar nos relatos a seguir:

Eu tô ansioso, [...] Ansioso pra chegar no meu trabalho, já que eu não posso fazer a parte do trabalho pesado, vou fazer a parte mais fraquinha [...] começar a movimentar o corpo, épelo trabalho que eu mantenho as minhas crianças (Hermes).

Mudou a facilidade que eu tinha de arrumar trabalho [...] As pessoas acham que eu não sou mais capaz de fazer muita coisa... (Zeus).

Tô afastado do trabalho [...] Além de eu tá dependendo dos outros, tá complicado, porque eu ajudava nas contas [...] Mas agora é só minha sogra que tá mantendo [...] Onde é que eu vou arrumar dinheiro? Ninguém quer me emprestar, eu não tenho condiçôes de pagar (Thor).

Eu tenho dificuldade, porque meu braço não estica [...] só até aqui, [...] porque devido à quelóide ter crescido impede o movimento do meu braço, não consegui retornar ainda ao trabalho, tô tentando conseguir o beneficio, por enquanto tô parado (Dionísio).

De acordo com Silva (2007), o que fornece significado ao trabalho é o propósito pelo qual ele e executado. É individual e específico para cada ser humano. Além disso, o que diferencia uma simples atividade de um trabalho é a razáo de sua realização, pois como o trabalho é uma ocupação, ele deve preencher uma finalidade e um valor, que é individual e subjetivo (SILVA, 2007). Outro aspecto que emergiu das entrevistas foi em relaçáo à ociosidade, principalmente relacionada à dificuldade de retornar ou se engajar nas ocupaçóes. Para os participantes desta pesquisa, que sempre trabalharam e que mantinham uma vida ativa, ter que ficar o dia inteiro em seu domicílio era muito incômodo. Percebeu-se, nos relatos, a necessidade em retornarem aos seus afazeres.

Agora que eu não tô podendo trabalhar, eu sinto muita falta [...] Ainda mais pra gente que é acostumado a trabalhar, ficar na casa, só naquela rotina de casa [...] Não é bom! (Hefesto).

Eu não posso trabalhar, poderia tá trabalhando e eu tô parado em casa, esperando o tempo, olhando o tempo passar [...] não faço nada (Helio).

Eu fico só em casa e fica chato né, porque a gente tá acostumado a ir pro trabalho, aquele horário, ir pro trabalho, voltar, assim é complicado [...] (Apolo).

Meu trabalho mudou um pouco, me sentia fraco [...] Mudou assim porque não vou poder apanhar açaí [...] Pois é, aí o jeito é ficar parado né, só na vontade de trabalhar [...] Eu gosto de trabalhar graças a Deus. Tenho 23 anos e nunca mexi em nada de ninguém [...] Ai por isso eu sempre gostei de trabalhar "pra mim" ter o que é meu (Ares).

Os significados são individuais e interagem com a forma ocupacional e contribuem para o desenvolvimento humano (KIELHOFNER; BARRET, 2002). Entretanto, a modificação na forma ocupacional pode provocar alteraçóes no significado do individuo sobre as suas ocupaçôes. Isso foi possível de ser compreendido a partir dos relatos dos participantes, principalmente em relação ao trabalho. Portanto, entende-se que quando uma pessoa é inviabilizada de exercer sua ocupação produtiva, como em decorrência da queimadura, vários âmbitos de sua vida são afetados, em geral, assumindo (o acidente) uma conotação negativa.

Outra área de ocupação também manifestada pelos participantes dessa pesquisa foi o lazer. A Associaçáo Americana de terapia ocupacional 
(AMERICAN..., 2014) considera o lazer uma atividade não obrigatória, motivada intrinsecamente e realizada durante o tempo livre, ou seja, de maneira diferente a de ocupaçôes obrigatórias tais como o trabalho, o autocuidado e o sono. Envolve a exploração e a participação. Durante as entrevistas, os participantes relataram sobre as dificuldades em retornar a estas ocupaçóes.

É importante ter lazer também, lazer é tudo [...] A pessoa se diverte, brinca tudo com sua familia, amigos, é muito bom, principalmente, no final de semana [...] Mas eu por enquanto, isso eu não tô tendo ainda, principalmente, porque a minha família não mora aqui né, é de longe [...] Aí eu tô aqui mesmo só me recuperando (Poseidon).

Eu gostava de sair nos fins de semana com a minha esposa, meus filhos, pra ir pro igarapé. Eu sempre gostei muito de sair, de brincar com meus amigos, gostava de festa, de tomar minha cervejinha, $e$ isso eu não faço mais [...] Não posso sair na rua, porque não pode pegar Sol, muitas coisas, não posso jogar bola... (Cronos).

Bom, eu não posso pegar Sol [...] Tenho que sair de carro e a noite e eu náo tenho carro [...] Eu fico o dia inteiro em casa, aí eu só tenho vida social através da internet e amigos [...] Assim, os que vão me visitar de vez em quando ou eu vou à casa da minha família [...] O lazer pra mim é importante, porque ele descansa e não é só a pessoa que trabalha que fica estressada [...] e eu ainda fiz meu marido tirar licença. Então, ficam os dois estressados em casa (Gaia).

Antes do acidente eu passeava, eu ia pra praia, eu ia pra restaurante tá, eu gostava na escola de participar, tudo eu participava [...] Eu cantava, dançava, brincava, pulava, sempre estava fazendo essas atividades [...] Mudou tudo isso, eu tive que parar um pouquinho, até por causa do repouso (Atena).

Através dos relatos, observou-se que as queimaduras trouxeram mudanças na forma ocupacional referente ao lazer, por vários motivos: restrição à exposição ao sol (evitar o surgimento de manchas na pele), sequelas físicas incapacitantes, alteraçóes na imagem corporal (sentimento de vergonha em decorrências de sequelas estéticas), entre outros. Todos esses fatores contribuíram para que ocorressem mudanças no envolvimento em ocupaçóes de lazer. Assim, as sequelas da queimadura, o tratamento e as repercussóes psicoemocionais decorrentes da queimadura geraram mudanças quanto à forma do engajamento em ocupações: autocuidado, produtividade e lazer. A dificuldade ou, em alguns casos, a impossibilidade de desempenhar ocupaçôes significativas repercutiu na saúde, assim como na qualidade do viver dessas pessoas.

\section{Conclusão}

O estudo centrou-se na investigação das repercussóes da queimadura na forma ocupacional das ocupaçôes. Percebeu-se que ocorreram significativas mudanças na forma das ocupaçóes. Estas repercutiram na saúde, bem-estar e qualidade do viver das pessoas participantes desta pesquisa. As alteraçóes estavam relacionadas principalmente com limitaçôes físico-funcionais, pois muitos pacientes não conseguiam desempenhar suas ocupaçóes em decorrência das sequelas deixadas pela queimadura, além de sentimentos de tristeza, sensação de impotência e invalidez e angústia por não conseguirem retornar às suas atividades habituais.

Dessa forma, este estudo adentrou neste campo e percebeu-se que há poucas investigaçôes que busquem compreender algo táo intrínseco à profissão, que é o estudo sobre como ficam as ocupaçóes após um acidente, em especial com pessoas que vivenciaram a situação de estarem queimadas. Através dos relatos, observou-se o quanto a experiência de estar queimado é única e singular, assim como o processo de enfrentamento desta condição. Durante as entrevistas, algumas pessoas ficaram bastante emocionadas, apresentando choro, outras faziam pausas antes de continuarem seus relatos, outras se mostravam aliviadas ao falar sobre o assunto. Dessa forma, defende-se a necessidade de ampliar os cuidados às vítimas de queimadura, pois devem ser assistidas de forma humanizada por uma equipe multiprofissional que garanta uma assistência integral em consonância com reais demandas dessas pessoas e que permita aprimorar as abordagens e intervençóes no campo clínico-assistencial.

Por fim, este estudo contribuiu para o aprimoramento do conhecimento quanto à problemática das repercussóes da queimadura para a ocupação humana, destaca-se a importância da atuação da terapia ocupacional na assistência, a partir de uma perspectiva ampliada e integral da saúde e da compreensão biopsicossocial e ocupacional do ser humano.

Uma das limitações deste estudo foi a amostragem, pois englobou apenas pessoas de um mesmo hospital e, então, os resultados observados podem ter sido influenciados pelas circunstâncias organizativas dessa mesma instituição. Assim sendo, não podemos generalizar os resultados obtidos em outras instituiçóes. 


\section{Referências}

AMERICAN OCCUPATIONAL THERAPY ASSOCIATION. Occupational therapy practice framework: domain and process. American Journal of Occupational Therapy, New York, v. 68, p. 1-48, 2014. Suplemento 1.

ANDRADE, C. C.; HOLANDA, A. F. Apontamentos sobre pesquisa qualitativa e pesquisa empírico-fenomenológica. Estudos de Psicologia, Campinas, v. 27, n. 2, p. 259-268, 2010.

ARAÚJO, L. S. et al. Ciencia de la ocupación y terapia ocupacional: sus relaciones y aplicaciones a la práctica clínica. Revista Chilena de Terapia Ocupacional, Santiago, v. 11, n. 1, p. 79-87, 2011.

ARRUDA, C. N.; BRAIDE, A. S. G.; NATIONS, M. "Carne crua e torrada": a experiência do sofrimento de ser queimada em mulheres nordestinas, Brasil. Cadernos de Saúde Pública, Rio de Janeiro, v. 30, n. 10, p. $2057-$ 2067, 2014.

CAVALCANTI, A. et al. Estrutura da prática da terapia ocupacional: domínio \& processo (3. ed). Revista de Terapia ocupacional da Universidade de São Paulo, Sáo Paulo, v. 26, p. 1-49, 2015. Edição especial.

CHRISTIANSEN, C.; BAUM, M. C.; BASS-HAUGEN, J. (Ed.). Occupational therapy: performance, participation and well-being. Thorofare: Slack, 2005.

ECHEVARRÍA-GUANILO, M. E. et al. Avaliação da qualidade de vida relacionada à saúde no primeiro ano após a queimadura. Escola Anna Nery Revista de Enfermagem, Rio de Janeiro, v. 20, n. 1, p. 155-166, 2016.

ECHEVERRÍA, R. T. A.; ORTEGA, L. T. P.; RIQUELME, E. V. Explorando necesidades ocupacionales: un estudio de caso. Revista Chilena de Terapia Ocupacional, Santiago, v. 9, n. 9, p. 117-131, 2009.

JACOBS, K.; JACOBS, L. Dicionário de terapia ocupacional. São Paulo: Roca, 2006.

KIELHOFNER, G.; BARRET, L. O modelo de ocupação humana. In: NEISTADT, M. E.; CREPEAU, E. B. (Org.). Terapia Ocupacional Willard \& Spackman. Rio de Janeiro: Guanabara Koogan, 2002. p. 490-492.

LARSON, E.; WOOD, W.; CLARCK, F. Ciencia Ocupacional: desarrollo de la ocupación através de uma disciplina acadêmica. In: CREPEAU, E. B.; COHN, E. S.; SCHELL, B. A. B. Willard \& Spackman: terapia ocupacional. Buenos Aires: Medica Panamericana, 2005. p. 16-26.
LEAO, C. E. G. et al. Epidemiologia das queimaduras no estado de Minas Gerais. Revista Brasileira de Cirurgia Plástica, São Paulo, v. 26, n. 4, p. 573-577, 2011.

LIRA, R. A.; SILVA, V. T. B. L.; SOANÉGENES, M. Intervenção terapêutica ocupacional a paciente vítima de queimadura elétrica na fase aguda. Revista Brasileira Queimaduras, Goiânia, v. 12, n. 1, p. 37-41, 2013.

MINAYO, M. C. S. O desafio do conhecimento: pesquisa qualitativa em saúde. São Paulo: Hucitec, 2004.

MINAYO, M. C. S. Análise qualitativa: teoria, passos e fidedignidade. Ciência e Saúde Coletiva, Rio de Janeiro, v. 17, n. 3, p. 621-626, 2012.

NELSON, D. L. Occupation: form and performance. American Journal of Occupational Therapy, Dearborn, v. 42, p. 633-641, 1988.

PINOCHET, M. C. D.; ARISMENDI, M. H.; CASTILLO, V. V. Análisis del significado de las ocupaciones atribuidas a ser mujer y madre para un grupo de mujeres con discapacidad intelectual en la ciudad de Punta Arenas. Santiago: Instituto Nacional de Derechos Humanos, 2013.

REY, L. Dicionário de termos técnicos de medicina e saúde. Rio de Janeiro: Guanabara Koogan, 2012.

RODRIGUES JÚNIOR, J. L.; BASTOS, N. N. A.; COELHO, P. A. S. Terapia ocupacional em queimados: pesquisa bibliográfica acerca da reabilitação física junto a indivíduos com queimaduras. Revista Brasileira Queimaduras, Goiânia, v. 13, n. 1, p. 11-17, 2014

SILVA, G. O significado do trabalho para o deficiente visual. 2007. 107 f. Dissertação (Mestrado em Saúde Pública) - Pontifícia Universidade Católica de Minas Gerais, Belo Horizonte, 2007.

SIQUEIRA, F. M. B.; JULIBONI, E. P. K. O papel da atividade terapêutica na reabilitaçáo do indivíduo queimado na fase aguda. Cadernos de Terapia Ocupacional da UFSCar, São Carlos, v. 8, n. 2, p. 79-81, 2000.

SOUZA, T. J. A. Qualidade de vida do paciente internado em uma unidade de queimados. Revista Brasileira de Cirurgia Plástica, São Paulo, v. 26, n. 1, p. 10-15, 2011.

TURATO, E. R. Tratado da metodologia da pesquisa clínico-qualitativa: construção teórico-epistemológico, discussão comparada e aplicação nas áreas da saúde e humanas. Petrópolis: Vozes, 2005.

WILCOCK, A. A theory of the human need for occupation. Journal of Occupational Science, Boca Raton, v. 1, n. 1, p. 17-24, 1993.

\section{Contribuição dos Autores}

Elson Ferreira Costa e Luísa de Sousa Monteiro participaram do projeto, da obtenção, análise e discussão dos dados, além da elaboração e revisão do texto. Victor Augusto Cavaleiro Corrêa coordenou e orientou a pesquisa, participando da análise, discussão e interpretação dos dados, além da elaboração e revisão do texto. Todos os autores aprovaram a versão final do texto. 


\section{Notas}

${ }^{1}$ Esta pesquisa é parte do Trabalho de Conclusão de Curso apresentado ao Centro de Ciências Biológicas e da Saúde da Universidade do Estado do Pará como requisito parcial para obtençáo do grau em terapia ocupacional, aprovada pelo comitê de ética e pesquisa da Fundação Hospital de Clínicas Gaspar Viana - FHCGV, protocolo No 188/2010.

${ }^{2}$ Desempenho ocupacional: habilidades para realizar atividades ocupacionais, que incluem atividades de vida diária, atividades instrumentais de vida diária, trabalho, educação, lazer, participação social, dormir e descansar. O desempenho ocupacional é resultado de uma transação dinâmica entre pessoa, contexto e atividade (JACOBS; JACOBS, 2006).

${ }^{3}$ Amplitude de movimento: movimento das partes do corpo através de um arco; trajetória de movimento articular, que pode ocorrer em uma direção; quantidade de movimento em determinada articulação (JACOBS; JACOBS, 2006).

${ }^{4}$ Parestesia: sensação anormal, como ardor, formigamento, prurido etc. percebidos na pele e sem motivo aparente, mas relacionados frequentemente com irritaçáo ou trauma de nervos sensitivos ou raízes nervosas (REY, 2012).

${ }^{5}$ Prurido: sensação desagradável, ao nível do tegumento, que leva o indivíduo a coçar-se; coceira. O prurido e a cócega são explicados pela estimulação leve de terminais nervosos livres, de fibras do tipo C (REY, 2012). 